\title{
Pelatihan Grafik Maple dalam Pembelajaran Matematika
}

\author{
Retno Marsitin*1, Nyamik Rahayu Sesanti ${ }^{2}$ \\ ${ }^{1}$ Pendidikan Matematika, Fakultas Sains dan Teknologi, Universitas Kanjuruhan Malang \\ ${ }^{2}$ PGSD, Fakultas Ilmu Pendidikan, Universitas Kanjuruhan Malang \\ e-mail: ․․ mars_retno@unikama.ac.id,²nyamik@unikama.ac.id
}

Informasi Artikel

Diterima Redaksi: 30 April 2020

Revisi Akhir: 30 mei 2020

Diterbitkan Online: 1 juni 2020

Kata Kunci:

Grafik Maple. Matematika, Pelatihan

\section{Abstrak}

Saat ini, guru matematika harus menerapkan pembelajaran matematika menggunakan teknologi, terutama untuk guru matematika kejuruan. Aplikasi teknologi yang dapat digunakan dalam pembelajaran matematika termasuk maple. Maple adalah perangkat lunak matematika yang mengintegrasikan kemampuan komputasi baik simbolik dan numerik, grafik sangat berpengaruh untuk membantu dalam memecahkan masalah matematika. Metode yang ditawarkan dalam memecahkan masalah mitra adalah dengan menyelenggarakan pelatihan grafik maple dan bimbingan dalam menerapkan grafik maple dalam pembelajaran matematika. Keberhasilan kegiatan pengabdian masyarakat ini didukung oleh beberapa faktor, yaitu: minat dan keinginan yang tinggi untuk berpartisipasi dalam kegiatan pelatihan sampai selesai, minat dan dukungan dari Singosari PGRI Vocational School sebagai sekolah mitra dalam kegiatan pelatihan maple graph, keterlibatan aktif sehingga ada saling berbagi pengetahuan tentang grafis maple. Kegiatan pengabdian masyarakat dengan pelatihan grafik maple mendapat respons positif dari guru kejuruan dengan pencapaian $93 \%$, hasil penyajian grafik maple dengan prestasi sangat baik adalah $87 \%$. Kegiatan pengabdian masyarakat ini dengan pelatihan grafik maple untuk guru Singosari PGRI Vocational School sangat berguna dalam menambah wawasan pengetahuan komputer, terutama penggunaan grafis maple, dan menumbuhkan kreativitas dan keterampilan dalam menggunakan grafik maple dalam pembelajaran matematika.

menarik minat peserta didik dalam belajar matematika. Guru matematika dituntut agar dapat menyesuaikan dengan perkembangan teknologi dengan berinovasi dalam pembelajaran matematika. Permasalahan matematika telah banyak yang dapat diselesaikan dengan memanfaatkan teknologi sehingga dapat mengatasi kesulitan matematika terutama dalam menggambar grafik matematika.

Menggambar grafik matematika dengan memanfaatkan teknologi menghasilkan grafik yang sangat baik, diantaranya dengan mengapilkasikan software matematika. Selain itu, olimpiade matematika tingkat Sekolah Menengah Atas ataupun Sekolah Menengah Kejuruan dan yang sederajat selalu menggunakan software matematika dan guru matematika diharapkan mampu diharapkan berbasis teknologi agar lebih 
menguasai software matematika. Berkenaan dengan hal tersebut maka diperlukan pelatihan agar dapat mengaplikasikan teknologi dalam pembelajaran matematika terutama menggambar grafik dengan software matematika.

Pembelajaran dengan menerapkan teknologi sangat bermanfaat bagi matematika terutama dalam aplikasi software matematika [2]. Pengalaman yang menyenangkan jika tenaga pendidik dalam pembelajaran matematika menggunakan suatu aplikasi yang menarik, dengan mengakses internet dan menggunakan software matematika [3]. Aplikasi teknologi dengan software matematika yang dapat dimanfaatkan dalam pembelajaran matematika diantaranya maple.

Maple merupakan software matematika yang mengintegrasikan kemampuan komputasi baik simbolik maupun numerik, grafik yang sangat berperan dalan membantu menyelesaikan permasalahan soal matematika. Kemampuan maple dapat mengubah susunan representasi yang berbeda seperti gambar, tabel, grafik, dan symbol memungkinkan pengajar dapat menyajikan pengetahuan matematika yang lebih luas. Maple sangat berperan dalam membantu seseorang yang sedang mencari penyelesaian matematis secara mudah dan cepat tanpa harus terjebak pada kesulitan atau kerumitan komputer [4].

Kemampuan yang dimiliki maple menumbuhkan minat, motivasi dan sikap positif khususnya terhadap matematika selain sesuai dengan karakteristik konsep matematika yang memerlukan penyajian secara tepat dan akurat, membutuhkan gambaran proses, menumbuhkan kegiatan eksplorasi dan menjadikan konsep matematika khususnya kalkulus yang dapat disajikan sebagai materi pembelajaran yang menyenangkan dan menarik, sehingga diharapkan akan meningkatkan pemahaman matematik dan komunikasi matematik terhadap kalkulus.

Keunggulan maple merupakan suatu paket program matematik diantaranya: a) maple merupakan program yang interaktif yang memungkinkan komputasi matematika dengan melibatkan simbol-simbol; b) maple memuat paket-paket matematika yang siap pakai dalam jumlah yang cukup banyak sehingga maple unggul dalam pengerjaan matematika; c) maple dapat digunakan sebagai bahasa pemrograman sehingga pengguna dapat mengimplementasikan algoritma matematika baru.

Mencermati fenomena permasalahan yang demikian, maka bersama SMK PGRI Singosari sebagai mitra berupaya menyelesaikan permasalahan dengan melakukan pengabdian berupa pelatihan grafik maple dalam pembelajaran matematika. Kegiatan pengabdian dengan pelatihan grafik maple bertujuan untuk meningkatkan wawasan pengetahuan dan ketrampilan dalam mengaplikasikan grafik maple pada pembelajaran matematika.

\section{METODE}

Metode yang ditawarkan dalam menyelesaikan permasalahan mitra dengan menyelenggarakan pelatihan grafik maple dan pendampingan dalam mengaplikasikan grafik maple pada pembelajaran matematika. Jenis pelaksanaan kegiatan pengabdian pada masyarakat ini adalah berbentuk pelatihan grafik maple yaitu menginstal maple, memberikan materi \& dialog interaktif dengan demonstrasi/simulasi/praktik grafik maple, dilanjutkan presentasi aplikasi grafik maple dalam pembelajaran matematika dan evaluasi sebagi indikator keberhasilan pelaksanaan kegiatan pengabdian.

Pelaksanaan pelatihan grafik maple menggunakan laptop atau android. Sasaran kegiatan pengabdian masyarakat yaitu guruguru SMK PGRI Singosari. Materi pelatihan grafik maple dikemas dalam modul pelatihan yang meliputi: pengantar dasar maple dalam matematika, ketrampilan menggambar grafik fungsi dalam maple, ketrampilan menggambar grafik turunan dalam maple, ketrampilan menggambar grafik integral dalam maple, ketrampilan kreativitas menggambar grafik maple dalam dua dimensi dan kreativitas mengaplikasikan grafik maple dalam pembelajaran matematika.

\section{HASIL DAN PEMBAHASAN}

Kegiatan pengabdian dengan pelatihan grafik maple diharapkan dapat meningkatkan wawasan pengetahuan dan ketrampilan dalam mengaplikasikan grafik 
maple pada pembelajaran matematika. Kegiatan pelatihan grafik maple dalam pembelajaran matematika memberikan manfaat bagi guru SMK dalam pembelajaran matematika yaitu:

a. meningkatkan ketrampilam dalam mengaplikasikan symbol, grafik maupun penyelesaian hitungan matematika secara tepat dan teliti;

b. meningkatkan ketrampilan dalam menyelesaikan grafik matematika dalam waktu yang singkat, misalnya grafik fungsi, grafik turunan, grafik integral dengan akurat, cepat dan tepat melalui maple;

c. meningkatkan kreativitas dalam mengoperasikan dan mengaplikasikan maple dalam pembelajaran matematika;

d. meningkatkan ketrampilan teknologi bagi guru matematika SMK dalam perkembangan teknologi.

Kegiatan pengabdian dengan pelatihan grafik maple yaitu: menginstal maple, memberikan materi \& dialog interaktif dengan demonstrasi/simulasi/praktik grafik maple, dilanjutkan presentasi aplikasi grafik maple dalam pembelajaran matematika dan evaluasi sebagai indikator keberhasilan pelaksanaan kegiatan pengabdian. Kegiatan pelatihan grafik maple mendapatkan tanggapan dan respon yang baik dan positif. Hal ini terbukti dari hasil pelaksanaan kegiatan pelatihan grafik maple yang dinilai cukup berhasil dengan kehadiran pada acara pelaksanaan pelatihan.

Pelaksanaan pelatihan grafik maple dengan materi pelatihan grafik maple yang dikemas dalam modul pelatihan yang meliputi: pengantar dasar maple dalam matematika, ketrampilan menggambar grafik fungsi dalam maple, ketrampilan menggambar grafik turunan dalam maple, ketrampilan menggambar grafik integral dalam maple, ketrampilan kreativitas menggambar grafik maple dalam dua dimensi dan kreativitas mengaplikasikan grafik maple dalam pembelajaran matematika.

Modul pelatihan grafik maple memaparkan penggunaan software maple dalam aplikasi grafik matematika baik perhitungan matematika maupun menggambar grafik matematika, yang diuraikan secara rinci baik penjelasan langkah dalam aplikasinya maupun contoh soal serta latihan soal. Kegiatan pengabdian pelatihan grafik maple tampak pada gambar berikut:
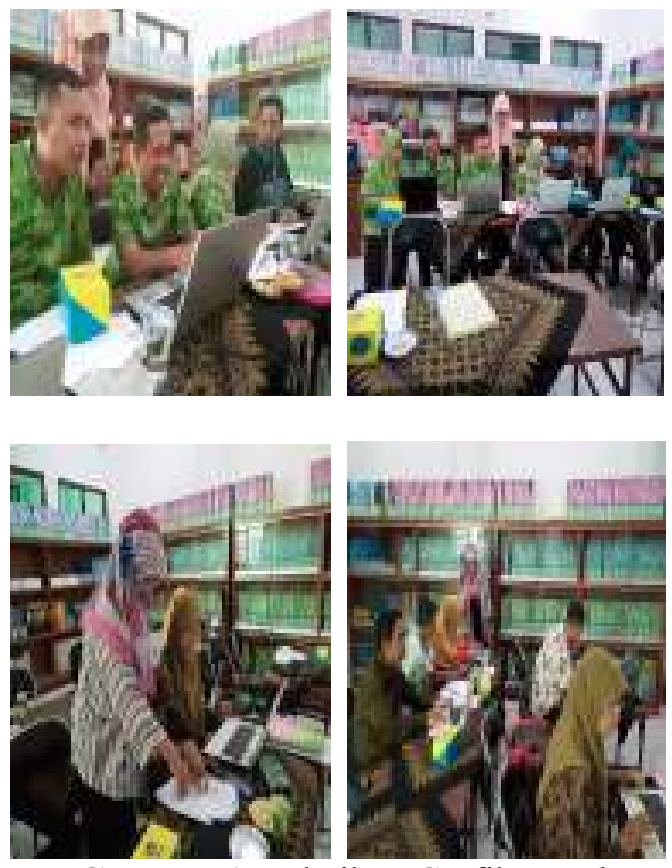

Gambar 1. Pelatihan Grafik Maple

Kegiatan pengabdian dengan pelatihan grafik maple mendapat respon yang positif dari guru SMK dengan ketercapaian 93\%, hasil presentasi grafik maple dengan ketercapaian sangat baik $87 \%$. Pelatihan grafik maple dapat meningkatkan keterlibatan guru SMK dalam memanfaatkan teknologi pada pembelajaran matematika SMK, menumbuhkan minat dalam menyelesaikan permasalahan matematika kalkulus dengan menggunakan grafik maple.

Hal ini sesuai dengan pendapat [5] bahwa proses pelaksanaan program pengabdian dalam bentuk pelatihan dengan orientasi praktik dan pelatihan dengan mengedepankan prinsip partnership yang menjadikan proses berlangsung interaktif dan dinamis berkembang secara konstruktif.

Keberhasilan kegiatan pelatihan ini dengan faktor pendukung yaitu: minat dan keinginan yang tinggi dari guru SMK dalam mengikuti kegiatan pelatihan hingga selesai, ketertarikan dan dukungan dari SMK PGRI Singosari sebagai sekolah mitra dalam 
melaksanakan kegiatan pelatihan grafik maple, respon yang positif sehingga terjalin saling sharing wawasan ilmu tentang grafik maple, keterlibatan secara aktif yang tampak antusiasme saat pelatihan grafik maple.

Kegiatan pengabdian masyarakat dengan pelatihan grafik maple bagi guru SMK PGRI Singosari sangat bermanfaat dalam menambah wawasan pengetahuan komputer terutama penggunaan grafik maple, serta menumbuhkan kreativitas dan ketrampilan dalam menggunakan grafik maple dalam pembelajaran matematika.

Hal ini sesuai dengan pendapat $[6,7]$ yang menyatakan bahwa guru sebagai aktor utama dalam proses pendidikan dituntut harus cepat memperbaharui pengetahuan, keterampilan, dan kompetensinya dalam bidang Teknologi Informasi dan Komunikasi (TIK), tak terkecuali guru produktif Sekolah Menengah Kejuruan (SMK).

Pelaksanaan kegiatan pengabdian dengan pelatihan grafik maple saling menguntungkan baik bagi pelaksana maupun mitra. Bagi pelaksana, selain untuk melaksanakan tri dharma perguruan tinggi juga mendapatkan kredit point kinerja, sedangkan bagi mitra dapat meningkatkan wawasan pengetahuan dan ketrampilan dalam mengaplikasikan grafik maple pada pembelajaran matematika.

\section{KESIMPULAN}

Kegiatan pengabdian pelatihan grafik maple mendapatkan tanggapan dan respon yang baik dan positif serta termotivasi secara aktif dalam mengikuti kegiatan sampai tuntas. Kegiatan pengabdian masyarakat dengan pelatihan grafik maple bagi guru SMK PGRI Singosari sangat bermanfaat dalam menambah wawasan pengetahuan komputer terutama penggunaan grafik maple, serta menumbuhkan kreativitas dan ketrampilan dalam menggunakan grafik maple dalam pembelajaran matematika. Kegiatan pengabdian dengan pelatihan grafik maple dapat meningkatkan wawasan pengetahuan dan ketrampilan dalam mengaplikasikan grafik maple pada pembelajaran matematika.

\section{SARAN}

Pelaksanan kegiatan pengabdian pelatihan software matematika sangat diperlukan bagi guru-guru SMK agar dapat berinovasi dalam pembelajaran matematika dengan memanfaatkan teknologi, sehingga pembelajaran matematika lebih menarik minat peserta didik dalam matematika.

\section{UCAPAN TERIMA KASIH}

Ucapan terima kasih disampaikan kepada Lembaga Penelitian dan Pengabdian Kepada Masyarakat (LPPM) Universitas Kanjuruhan Malang dan SMK PGRI Singosari Kabupaten Malang atas dukungan dan kerjasamanya dalam pelaksanaan kegiatan pengabdian.

\section{REFERENSI}

[1] NCTM, 2000, Principles and Standards for School Mathematics

[2] Marsitin, Retno; Rahayu sesanti N, 2016, Pelatihan Software Matematika Maple bagi Mahasiswa Pendidikan Matematika Universitas Kanjuruhan Malange Seminar Nasional Pengabdian Masyarakat 2016 pp 204-8

[3] Furner J M, Yahya N and Duffy M Lou, 2005, Teach mathematics: Strategies to reach all students Interv. Sch. Clin.

[4] Marsitin R and Rahayu Sesanti N, 2018, Limit Learning With Apos Theory and Maple to Develop Mathematical Communication And Critical Thinking (Atlantis Press)

[5] Zuriah N, Sunaryo H and Yusuf N, 2016, IbM GURU DALAM PENGEMBANGAN BAHAN AJAR KREATIF INOVATIF BERBASIS POTENSI LOKAL $J$. Dedik.

[6] Fitriyadi H, 2013, Keterampilan TIK guru produktif SMK di Kabupaten Hulu Sungai Utara dan implementasinya dalam pembelajaran J. Pendidik. Vokasi

[7] Munir, 2009, Kontribusi Teknologi informasi dan Komunikasi (TIK) dalam Pendidikan di Era Globalisasi Pendidikan Indonesia J. Pendidik. Teknol. Inf. dan Komun. 